\title{
Large cruzianid trace fossils in the Ordovician of the peri-Baltic area: the case of the Bukówka Formation (Holy Cross Mountains, Poland)
}

\author{
Michał STACHACZ ${ }^{1, *}$, Weronika $Ł A S K A^{1}$ and Alfred UCHMAN ${ }^{1}$ \\ 1 Jagiellonian University, Institute of Geological Sciences, Gronostajowa 3a, 30-387 Kraków, Poland
}

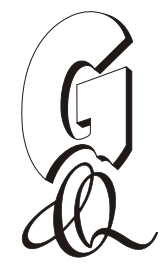

Stachacz, M., Łaska, W., Uchman, A., 2018. Large cruzianid trace fossils in the Ordovician of the peri-Baltic area: the case of the Bukówka Formation (Holy Cross Mountains, Poland). Geological Quarterly, 62 (2): 400-414, doi: 10.7306/gq.1412

\begin{abstract}
The Middle Ordovician Bukówka Formation, composed of fine-grained quartz sandstones with siltstone intercalations, belongs to the Kielce Region of the Holy Cross Mountains (peri-Baltic palaeogeographic position). It contains trace fossils of low diversity and poor preservation. Particularly noteworthy are the large Cruziana and Rusophycus, that are typical of peri-Gondwanan areas. They consist of casts of bilobate furrows showing diverse preservation. Other trace fossils include mostly horizontal pascichnia, cubichnia, and fodinichnia, but also vertical domichnia. The trace fossil assemblage is typical of the archetypal Cruziana and partly of the Skolithos ichnofacies. Some beds contain abundant orthid brachiopods. The trace fossils and sedimentary structures (horizontal, low-angle and wave ripple cross-laminations, hummocky cross-stratification) suggest deposition on the middle and lower shoreface with storm influence. The poor preservation and low diversity of the trace fossils are related to the homogeneous lithology, low accumulation rate, shallow burial of organic matter and strong bioturbation. Therefore, animals burrowed strongly but mostly in shallow tiers. Thus, the preservation potential of their traces was much lower than in many peri-Gondwanan sections but still higher than in Baltica sedimentary rocks. This explains the provincial differences in ichnofauna during the Ordovician, which at least partly were influenced by the preservation potential.
\end{abstract}

Key words: Ordovician, trace fossils, bioturbation, Cruziana, taphonomy, Baltica.

\section{INTRODUCTION}

Lower Paleozoic trace fossils show some provincial specificity (e.g., Seilacher, 1992, 2007; Servais et al., 2010). For instance, those from the Ordovician System of Gondwana (e.g., d'Orbigny, 1842; Rouault, 1850; Lebesconte, 1883, 1886; Delgado, 1886; Seilacher, 1970; Baldwin, 1977a; Durand, 1984, 1985a, b; Neto de Carvalho, 2006) are characterized by an abundance of large trilobite burrows, which are much rarer in Baltica. At least partly, this could be an effect of differences in facies, because Gondwanan clastic, usually heterolithic sediments are more suitable for trace fossil preservation than are the more homogeneous clastic or carbonate lithologies prevailing in Baltica (e.g., Rodríguez-Tovar et al., 2014) or an effect of insufficient survey. In this paper, a trace fossil assemblage including large trilobite burrows is described from the Ordovician of the Holy Cross Mountains in central Poland. The Bukówka Formation studied belongs to the Kielce Region, a part of the Małopolska Block, which palaeogeographically is considered as a peri-Baltic terrain (Cocks and Torsvik, 2002). This may shed light on provincial differences between the Gondwana and

\section{*Corresponding author, e-mail: michal.stachacz@uj.edu.pl}

Received: November 21, 2017; accepted: January 22, 2018; first published online: May 8, 2018
Baltica ichnological record. M oreover, this ichnological analysis provides insight into the depositional palaeoenvironment of the Bukówka Formation, which has lacked detailed ichnological studies. Only Trela (2006) noticed a high degree of bioturbation. Body fossils of the formation were described by authors including Bednarczyk (1971), Bednarczyk and Biernat (1978), Dzik and Pisera (1994), Bednarczyk and Stupnicka (2000).

\section{GEOLOGICAL SETTING}

The Ordovician of the Holy Cross Mountains is developed as a succession of siliciclastic and carbonaceous deposits of varied thickness that does not exceed 300 m (Skompski, 2015, for summary), but rather less than $100 \mathrm{~m}$ in the Kielce Region (cf. Trela, 2006). The facies development and thickness were influenced by tectonic rejuvenation of the sedimentary basin at the beginning of the Ordovician. Generally, Ordovician strata in the Kielce Region (the southern block of the Holy Cross Mountains) overlie the Cambrian strata with an angular unconformity, unlike the Łysogóry Region (northern block of the Holy Cross Mountains), which is characterized by a conformable sedimentary contact between Cambrian and Ordovician rocks (e.g., Czarnocki, 1939; Bednarczyk, 1971). This region belongs to a larger structure called the Małopolska Block, which was situated on the Baltica margin during the Ordovician (e.g., Cocks, 2002) or between Baltica and Gondwana (Dzik and Pisera, 1994). 
The Middle Ordovician Bukówka Formation crops out in only a few places of the Kielce Region, mainly in inactive quarries of the Kielce area in the west and in the Międzygórz Quarry in the east. The Bukówka Formation is dated by the articulate brachiopods Antigonambonites planus (Pander), Lycophoria nucella (Dalman), Orthambonites calligramma (Dalman) and Productorthis obtusa (Pander) to the late Arenig-earliest Llanvirn (Bednarczyk, 1971; Dzik and Pisera, 1994; Trela, 2006; =late Dapingian-early Darriwilian, see Ogg et al., 2016), and is mainly represented by fine-grained quartz arenites with scarce intercalations of mudstones and siltstones. The quartz sandstones are generally replaced by carbonates toward the top of the formation (Trela, 2006). The Bukówka Formation lies above carbonates of the Szumsko Formation and it is separated from the overlying carbonates of the Mójcza Formation by an unconformity (Trela, 2006). The Bukówka Formation ranges greatly in thickness from 3 to $45 \mathrm{~m}$ and it is dated to the late Arenig and early Llanvirn (=late Dapingian and early Darriwilian, see Ogg et al., 2016; 470 $\mathrm{Ma}$ to $465 \mathrm{Ma}$ ) within three conodont zones (Paroistodus originalis, Baltoniodus norrlandiscus and Eoplacognathus variabilis) and two graptolite zones (Didymograptus hirundo Zone and Holmograptus lentus Subzone; Trela, 2006, based on Webby et al., 2004). According to Cooper and Sadler (2012; cf. Ogg et al., 2016), these biozones represent the late Dapingian-early Darriwilian, which cover $\sim 4.5 \mathrm{My}$ from 468.5 to $464 \mathrm{Ma}$ (see also Ogg et al., 2016). Bergström et al. (2008) proposed the regional subdivisions Volkhow and Kunda for Baltoscandia, which equal the late Dapingian and early Darriwilian. Nevertheless, the Baltoscandian subdivisions have been not yet been used for the Małopolska Block and precise correlation is difficult.

\section{LOCALITIES}

The Bukówka Formation was studied in two inactive quarries (Mójcza 1 and Mójcza 2) at Mójcza near Kielce, an inactive quarry at Międzygórz and a natural exposure among an unnamed stream tributary of the Czarna Staszowska River at Zalesie near Łagów (Kielce County; Fig. 1). Poor exposures in the ravine at Zalesie (GPS coordinates: N5050'29.2", E20 41 '11.4") have provided sparse data and this locality is protected by Polish law as monument of nature. Two small, inactive stone quarries at Mójcza area were examined in detail, bed-by-bed and all beds have been sampled and polished as part of the observations. About 300 rock slabs were prepared for detailed ichnological and sedimentological analyses. The catalogued samples are housed in the Institute of Geological Sciences of the Jagiellonian University in Kraków (institutional abbreviation: INGUJ214P/B).

The Bukówka Formation sandstones were exploited as building stones during the 20th century, but recently, most of the exploitation sites have been covered by vegetation. However, slabs of the sandstone are accessible in walls of the Diocese Museum on the Czerwonego Krzyża and Jana Pawła II streets, and in walls of the Polish Geological Institute, on Zgoda street, as well as on Zagórska street, all in Kielce. Some of the slabs contain determinable trace fossils.

Mójcza region. The Bukówka Formation is exposed in a few small, inactive quarries, where two sections, 2 and $4 \mathrm{~m}$ thick, were studied (Fig. 1). In addition, blocks of the unexposed top of the formation on Załaźna Hill at Mójcza were examined (GPS coordinates: N5050'29.2”, E2041'11.4”). Similar rocks are exposed in the stratotype of the Bukówka Formation at the

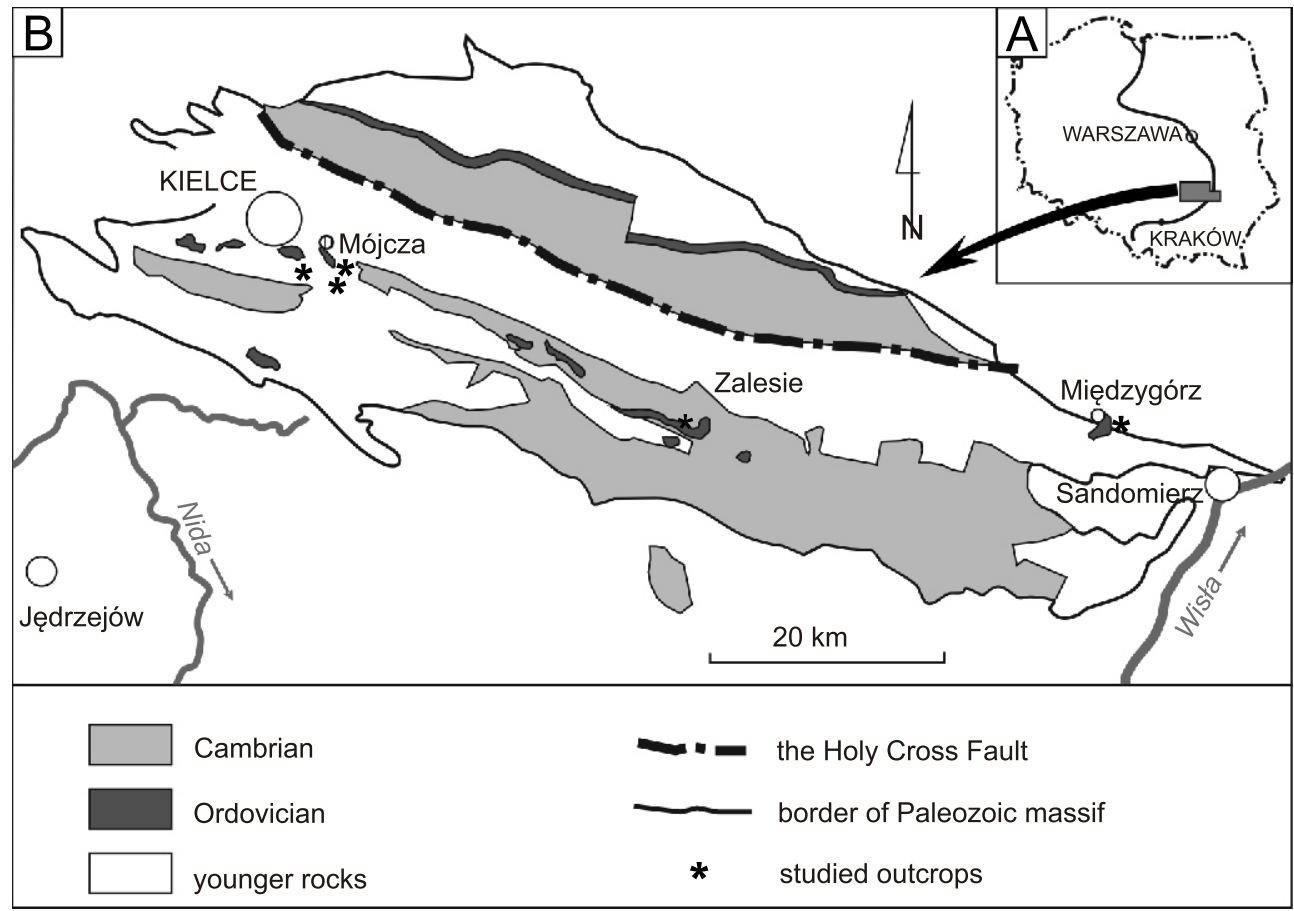

Fig. 1. Location maps

A - sketch map of Poland; B - simplified geological map of the Paleozoic core of the Holy Cross Mountains; the geology is based on Trela (1998) and references cited therein 


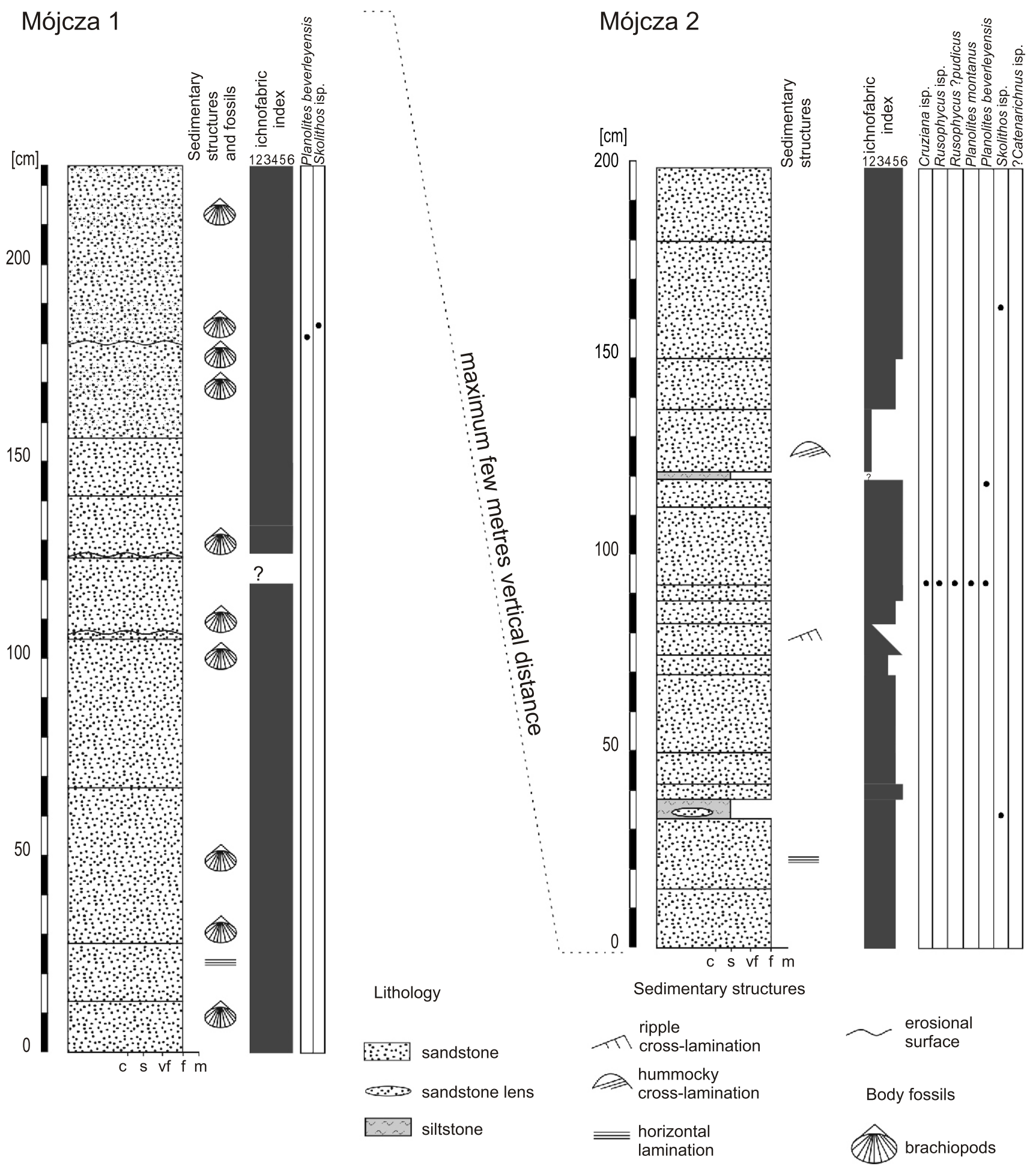

Fig. 2. Logs of the late Dapingian-early Darriwilian Bukówka Formation, Mójcza 1 (lower) and 2 (upper) sections

old quarry at Bukówka (Kielce district, GPS coordinates: N5050'16.1", E20³9'43.3"; Fig. 1). The formation in this area is composed of quartz arenites with sparse siltstones and mudstone intercalations. The rocks were mostly studied in two abandoned quarries Mójcza 1 and Mójcza 2, near Kielce. The Mójcza 1 section (GPS coordinates: N5050'16.7" E: $20^{\circ} 41^{\prime} 16.0$ "; Figs. 1 and 2 ) represents the lower part of the succession studied. The bioturbated quartz sandstone beds dip normally at $\sim 60^{\circ} / 19^{\circ}$. Several beds of this section contain mass accumulations of the brachiopods Orthis $\mathrm{sp}$. and
Orthanambonites sp., which are preserved almost exclusively as internal and external moulds (Figs. 2 and 3). However, calcite brachiopod shells and one horizon with moulds of the echinoderm Echinosphaerites are present at the top of the formation (Fig. 3), which since recently is no longer exposed. The shells form shell pavements in some beds. Similar rocks containing the same trace fossils and skeletal fossils of brachiopods and the gastropod ?Euomphalus (Fig. 3) probably come from the old Bukówka Quarry. They were observed in the wall slabs of several buildings in Kielce. 



Fig. 3. Primary sedimentary structures and body fossils in the sandstones of the Bukówka Formation of the Mójcza area

A, B - hummocky cross-stratification; C, D - coquina beds with orthid brachiopod fossils: C - only moulds and negatives, D well-preserved calcitic shells; E, F - Echinosphaerites sp.: E - individual specimen, $\mathrm{F}$ - horizon with abundant Echinosphaerites (E) and orthid brachiopods (O); G - gastropod ?Euomphalus, wall in Zagórska Street, Kielce 
In the Mójcza 2 section (GPS coordinates: N5050'18.7", E20 $41^{\prime} 19.8^{\prime \prime} ;$ Fig. 1 ), beds dip normally at $\sim 140^{\circ} / 15^{\circ}$ and represent the upper part of the succession studied. The sandstones are mostly wackes, which are mostly totally or almost totally bioturbated (ichnofabric index 4-5 sensu Droser and Bottjer, 1986). Primary sedimentary structures are scarce, and are represented by rare relicts of low-angle cross stratification, ripple and horizontal lamination (Fig. 2). A high content of matrix as well as fragments of reworked firmground intraclasts are common in several beds.

The sandy limestones in the upper part of the formation lying below the discontinuity at Mójcza, which were formerly ascribed to the Mójcza Formation by Dzik and Pisera (1994), were included in the Bukówka Formation by Trela (2006). The trace fossils from sandstones of the Mójcza sections belong to horizontal pascichnia and vertical domichnia. The pascichnia include Planolites montanus, $P$. beverleyensis, Palaeophycus isp. and Cruziana isp. The domichnia are represented by Skolithos isp. and ?Catenarichnus isp. The cubichnia include Rusophycus isp. and Rusophycus ?pudicus and fodinichnia Teichichnus isp.

Międzygórz Quarry. The quarry (GPS coordinates: N50'44'8.4", E21 $33^{\prime} 47.1^{\prime \prime} ;$ Fig. 1) exposes thick-bedded glauconitic sandstones and conglomerates of the Międzygórz Formation, sandstones of the Bukówka Formation, and very poorly exposed limestones of the Mójcza Formation (Dzik and Pisera, 1994; Bednarczyk and Stupnicka, 2000; Trela, 2006). Conglomerates of the Międzygórz Formation consist of 2-60 $\mathrm{mm}$ clasts and glauconitic matrix, which are interbedded with green, coarse-grained sandstones (Tomczyk, 1962; Tomczyk and Turnau-Morawska, 1967). They do not contain any trace fossils. The overlying Bukówka Formation is composed of yellowish and grey sandstones. The Bukówka Formation is poorly exposed in Międzygórz Quarry and does not show important differences in ichnological and sedimentological features between this quarry and rocks exposed in the Mójcza region, which were analysed in detail. According to Bednarczyk and Stupnicka (2000), the lithostratigraphic units in this quarry are cut by several faults. Therefore, it is impossible to measure the entire section.

\section{TRACE FOSSILS}

\section{Cruziana isp.}

(Fig. 4)

Material. - Two catalogued specimens, INGUJ214P/B3, B26; plus one specimen in a slab in the wall of the Polish Geological Institute on Zgoda street in Kielce.

$D$ e s c r i p t i o n. - A fragment of a large, high, indistinctly bilobate hypichnial ridge, $80-120 \mathrm{~mm}$ wide, $20-50 \mathrm{~mm}$ high, was observed for a length of $340 \mathrm{~mm}$. The lobes are separated by an indistinct, shallow furrow and covered by indistinct, variable, thicker and thinner scratch traces or imbricated scales (e.g., specimen INGUJ214P/B26). At the top of the lobes, blunt scratch traces 1-3 mm wide are present. They run almost perpendicular to the median furrow. The specimen INGUJ214P/B3 shows scratch traces in the external sides of the lobes. They are $\sim 0.5 \mathrm{~mm}$ wide, sharp, arcuate and oblique to the median furrow. The observed burrows are cross-cut by numerous Skolithos. Cross-sections of the burrow display a massive fill, which is lithologically the same as the host rock (Fig. 4C). The specimen in the wall of the building is preserved as an epichnial, bilobate furrow, which is $\sim 50 \mathrm{~mm}$ wide and shows a similar pattern of scratch traces.

$\mathrm{R}$ e $\mathrm{m}$ a rks. - The Cruziana collected and described is separated by a thin siltstone layer from the underlying sandstone bed. The thick scratch traces are poorly preserved. The specimens described, especially specimen INGUJ214P/B26, are quite similar to Cruziana imbricata Seilacher, 1970, but they show both an imbricated pattern and scratch traces, in contrast to C. imbricata, which displays no scratch traces (Seilacher, 1970). Nevertheless, their poor preservation prevents determination at the ichnospecies level. The sandstone bed bearing Cruziana is noticeably thicker around the trace. This suggests that the trace-making trilobite burrowed in a small, local depression on the seafloor. The absence of disturbance in the sandstone bed above the trace points to the predepositional origin of the trace by the filling of a furrow with sand brought in by currents (Baldwin 1977b), unlike the large, teichichnoid Cruziana from the Ordovician of Portugal, England and Spain (Goldring, 1985; Neto de Carvalho, 2006; Stachacz et al., 2015).

\section{Rusophycus isp. (Fig. 5A-D)}

M a t e r i a I. - Eight specimens, INGUJ214P/B1, B4, B5, B17, B2729.

Description. - Fragments of bilobate hypichnial mounds without distinct margins (Fig. $5 \mathrm{~A}-\mathrm{C}$ ) or with an indistinct slat at one side (Fig. 5D), 60-200 mm long, 60-110 mm wide, and $10-30 \mathrm{~mm}$ high. The median furrow is expanded on the frontal side, so the lobes show a cleft, V-shaped pattern. The lobes are covered by thick, irregular scratch traces, which are $\sim 1-5 \mathrm{~mm}$ wide. The scratch traces meet at an angle of $100-180^{\circ}$, being nearly perpendicular (Fig. $5 \mathrm{~A}$ ) or oblique to the median furrow. In the latter case, they form $\mathrm{V}$-shaped patterns oriented in opposite directions in the frontal and rear parts (Fig. 5B, C).

$\mathrm{R}$ e $\mathrm{m}$ a r k s. - Some specimens are so poorly preserved (Fig. 5A, B) that they resemble inorganic load casts. However, their true nature is revealed by the scratch traces or even moulds of limbs, seen in the indistinct marginal areas (Fig. 5B). The sandstone bed around Rusophycus isp. is relatively thick. This suggests that the trace-making trilobite burrowed in a small, local depression on the sea floor and next the bed was loaded during deposition on top of the trace, if the burrow was predepositional.

$$
\begin{gathered}
\text { Rusophycus ?pudicus Hall, } 1852 \\
\text { (Fig. 5E) }
\end{gathered}
$$

M a t e r i a I. - Two specimens, INGUJ214P/B2, B30.

$\mathrm{D}$ e s c r i p t i o n. - Elongate, bilobate hypichnial mound, wedge-shaped in outline, at least $130 \mathrm{~mm}$ long, 60-70 mm wide, $30 \mathrm{~mm}$ high, without distinct margins. The lobes are covered by more or less distinct, weakly developed scratch traces, which are $\sim 1 \mathrm{~mm}$ wide and 1-2 $\mathrm{mm}$ apart. They meet in the median furrow at different angles: at $90^{\circ}$ in the front part, with a transition to $120^{\circ}$ in the rear part. The scratch traces are curved in an arc and form a V-shaped pattern. They are oriented in opposite directions in the front and rear parts of the trace fossil. 



Fig. 4. Cruziana isp. from the Ordovician Bukówka Formation, Mójcza

A, B - general view of hypichnial convex semi-reliefs display scratch traces; associated trace fossils ( $S$ - Skolithos, $P-P l a n o l i t e s)$ occur: A - INGUJ214P/B3, B - INGUJ214P/B26; C - vertical section of the hypichnial convex semirelief with massive fill, INGUJ214P/B3

The scratch traces in the front part are slightly thicker than those in the rear part.

R e $\mathrm{m}$ a r k s. - The specimens described here are similar to Rusophycus pudicus Hall, 1852 from the Dominion Formation (Arenig, Wabana Group, Newfoundland, E Canada), illustrated by Fillion and Pickerill (1990: pl. 15.6) and personally observed, but its state of preservation does not permit such an exact determination. The trilobite Flexicalymene is considered as the producer of Rusophycus pudicus as its size and shape resembles the morphology of this trace fossil and imprints of its cephalic doublure and thoracic pleurae were observed in some specimens (Osgood, 1970). Moreover, Osgood (1970) found Flexicalymene meeki Foerste together with Rusophycus pudicus. Flexicalymene and other calymenids originated in Gondwana and were distributed around Gondwana, Laurentia and Baltica at the end of the Ordovician (Barnes et al., 1996).
Skolithos isp.

(Fig. 6A, B)

M a t e ri a I. - Seven sandstone slabs, INGUJ214P/B6, B9, B11, B13, B14, B16, B25, which contain more than thirty specimens. A few hundred specimens were observed in the field.

Description. - Vertical or sub-vertical pipe-like, lined shafts filled with sand, visible in vertical sections or on bedding surfaces. Most of the shafts are generally constant in width, at $\sim 5 \mathrm{~mm}$, and the largest are up to $18 \mathrm{~mm}$ in diameter. Their observed length, up to $100 \mathrm{~mm}$, depends on the bed thickness; it is longer in thicker beds. The pipes are densely packed in some beds. 



Fig. 5. Rusophycus from the Bukówka Formation at Mójcza

A, B - poorly preserved Rusophycus isp. with only partly visible scratch traces: A - hypichnial view, B - side view of the same specimen with limbs traces at the side arrowed, INGUJ214P/B4; C, D - bilobate specimens of Rusophycus isp. with distinct scratch traces, hypichnial convex semireliefs: C - INGUJ214P/B27, D - INGUJ214P/B1; E Rusophycus ?pudicus Hall, 1852, hypichnial convex semirelief, INGUJ214P/B2 

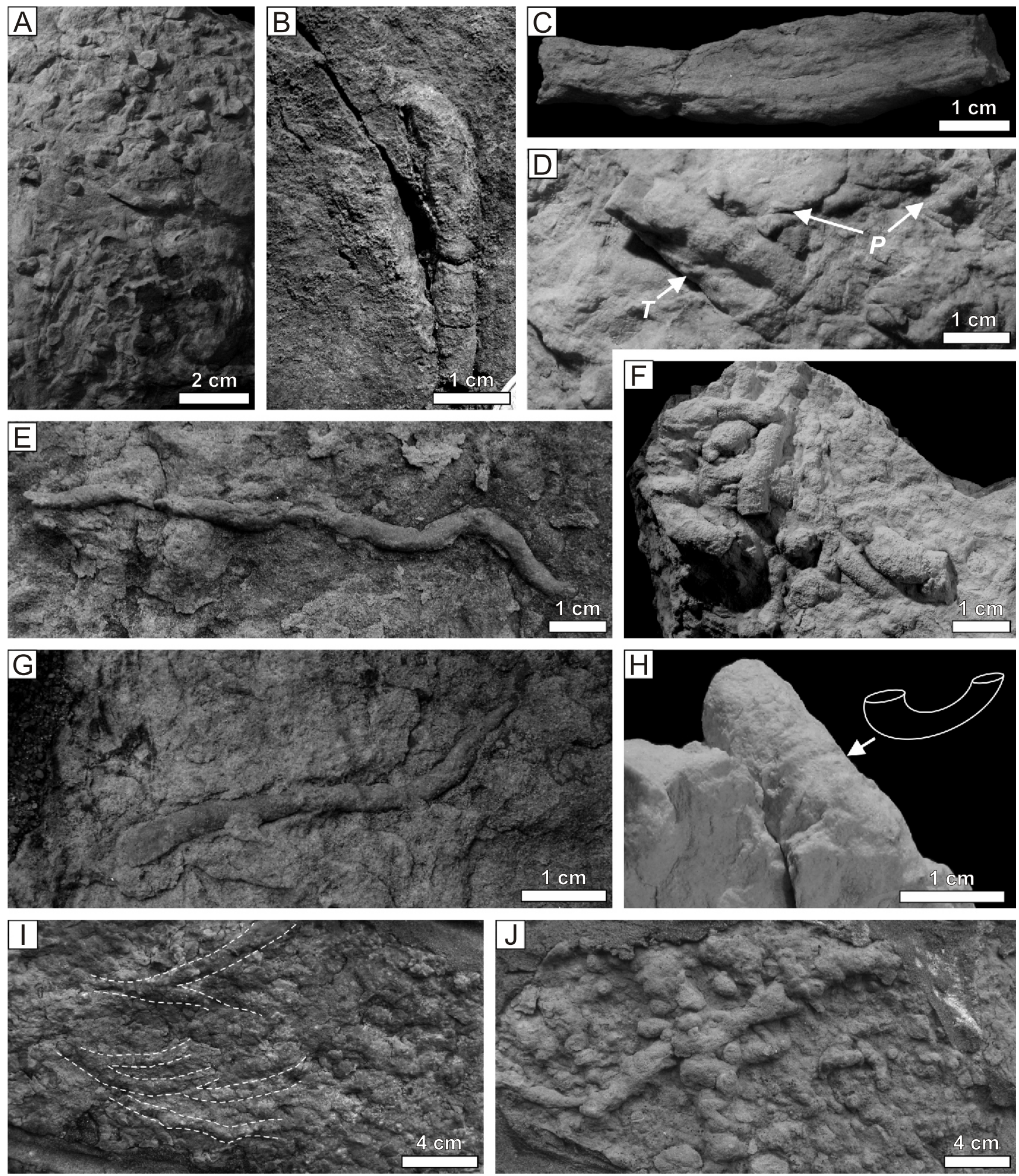

Fig. 6. Other trace fossils from the Bukówka Formation at Mójcza

A, B - Skolithos isp.: A - bioturbated upper bedding surface, INGUJ214P/B6, B - endichnion in sandstone bed, field photo; C, D Teichichnus rectus Seilacher, 1955 (T): C - endichnion separated from the host bed, side view, INGUJ214P/B24, D - endichnion in a thin sandstone bed, lower bedding surface, $P$ - Planolites, INGUJ214P/B31; E - Planolites beverleyensis (Billings, 1862), hypichnial convex semirelief, a slab in the wall by the Świętego Krzyża Street, Kielce; F - Planolites montanus Richter, 1937, hypichnial convex semi-relief, INGUJ214P/B7; G - Palaeophycus tubularis (Hall, 1847), endichnia in block of medium sandstone beds in the wall, Jana Pawła II street, Kielce; H - ?Catenarichnus isp., endichnion in a sandstone bed, NGUJ214P/B8; I - Phycodes cf. circinatus Richter, 1850; J ?Ptychoplasma isp; both specimens are hypichnia in the wall of the building of the Polish Geological Institute, Zgoda street, Kielce 
R e m a r k s. - According to Hallam and Swett (1966), truncated Monocraterion can be similar to Skolithos, however, the latter is usually lined, and no evidence of a funnel, a typical feature of Monocraterion (Schlirf and Uchman, 2005), was observed in the Skolithos isp. described. Skolithos is commonly interpreted as a domichnial burrow of suspension-feeding annelids or phoronids (Alpert, 1974; Fillion and Pickerill, 1990; Vinn and Wilson, 2013).

Teichichnus rectus Seilacher, 1955 (Fig. 6C, D)

M a te rial. - Two sandstone slabs INGUJ214P/B24, B31, five specimens observed in the field.

D e s c r i p t i o n. - Endichnial, wedge- or banana-shaped structures preserved in full relief with more or less distinct $\mathrm{U}$-shaped, retrusive spreites. The structure is $8-10 \mathrm{~mm}$ wide, 10-20 $\mathrm{mm}$ high, at least up to $65 \mathrm{~mm}$ long.

$\mathrm{R}$ e $\mathrm{m}$ a $\mathrm{r} \mathrm{k} \mathrm{s}$. - The specimens analysed vary in shape and size. Teichichnus rectus is the type ichnospecies of this ichnogenus, commonly interpreted as an equilibrium feeding structure (Corner and Fjalstad, 1993).

Planolites beverleyensis (Billings, 1862) (Fig. 6E)

M a terial. - Three specimens, INGUJ214P/B18-20, numerous specimens observed in the field.

D e s c r i p t i o n. - Horizontal, straight or slightly curved hypichnial ridge preserved in semirelief, semi-elliptical or semi-circular in cross-section, with smooth surface, at least $85 \mathrm{~mm}$ long. Its width ranges from 4 to $9 \mathrm{~mm}$ but it is uniform through the whole length. The ridges are filled by sandy material identical to that of the host sandstone bed.

$\mathrm{R}$ e $\mathrm{m}$ a r k s. - Some specimens preserved in sandstone (e.g., INGUJ214P/B20) are similar to Palaeophycus tubularis Hall, 1847. Nevertheless, the latter taxon differs by the presence of a wall (Pemberton and Frey, 1982; Fillion and Pickerill, 1990; Keighley and Pickerill, 1995). Planolites is present in many facies and it is interpreted as an actively filled pascichnion formed by worm-like deposit-feeders (e.g., Osgood, 1970; Pemberton and Frey, 1982; Fillion and Pickerill, 1990; Keighley and Pickerill, 1995).

Planolites montanus Richter, 1937

(Fig. 6F)

M a terial. - Two sandstone slabs (INGUJ214P/B7, B21) that contain several specimens; numerous specimens observed in the field.

D e s c r i p t i o n. - An endichnial full-relief cylinder or a hypichnial ridge, 3-5 $\mathrm{mm}$ wide, with smooth surfaces, preserved in full relief or semirelief. The burrow is curved, semi-oval in cross-section, changing course over short distances. Commonly, it protrudes from or plunges into the bed. Some specimens observed are preserved in a silty layer within a hummocky cross-stratified sandstone bed. The trace fossil is abundant in some sandstone beds and densely covers their soles (Fig. 6F).
R e m a r k s. - According to Pemberton and Frey (1982), Planolites montanus is relatively small, curved or contorted, up to $5 \mathrm{~mm}$ in diameter. However, the size of specimens is a less important diagnostic feature; more important is the characteristic orientation changing over short distances and relatively commonly plunging into the bed.

\section{Palaeophycus tubularis Hall, 1847} (Fig. 6G)

M a t e ri a l. - Five specimens observed in slabs in the wall of the Diocese Museum (Czerwonego Krzyża and Jana Pawła II streets, Kielce); a few specimens observed in the field.

D e s c r i p t i o n. - Endichnial, straight or slightly curved, unbranched tubes, 4-15 $\mathrm{mm}$ wide, from tens to $200 \mathrm{~mm}$ long, circular or oval in cross-section, with a more or less distinct wall. The filling is the same as the host sandstone.

$\mathrm{R}$ e $\mathrm{m}$ a r k s. - Some specimens are difficult to distinguish from Planolites beverleyensis (Billings, 1862). However, the presence of the wall indicates Palaeophycus tubularis (see Pemberton and Frey, 1982; Fillion and Pickerill, 1990; Keighley and Pickerill, 1995). Palaeophycus tubularis is mostly interpreted as a structure formed by deposit feeders and predators moving mainly along the sediment interfaces (e.g., Pemberton and Frey, 1982).

\section{?Catenarichnus isp. (Fig. 6H)}

Material. - One sandstone fragment (specimen INGUJ214P/B8) with two poorly preserved specimens. In addition, specimens in slabs in the wall of the building of the Polish Geological Institute, Zgoda street, Kielce.

$\mathrm{D}$ e s c r i p t i o n. - A J- or U-shaped burrow whose limbs diverge. The cylinder is $\sim 12 \mathrm{~mm}$ wide and $20-20 \mathrm{~mm}$ deep. The burrow is unlined. It has a rough surface and sandy filling, matching the host rock.

$\mathrm{R}$ e m a rks. - Catenarichnus Bradshaw, 2002 and its only ichnospecies C. antarcticus Bradshaw, 2002 from the Devonian of Antarctica is a vertical arc-like cylindrical burrow, with divergent limbs which plunge into the bed at a low angle. Catenichnus contentus McCarthy, 1979 is similar but it shows indistinct spreite and then differs from Arenicolites Salter, 1857. Arenicolites has parallel limbs and the aforementioned ichnogenera are characterized by divergent limbs (see Hofmann et al., 2011, Rodríguez-Tovar et al., 2014). A Cambrian trace fossil of this type with strongly divergent arms, determined as Arenicolites (Stachacz, 2016) may belong to Catenarichnus.

Phycodes cf. circinatus Richter, 1850 (Fig. 6I)

$\mathrm{M}$ a t e r i a l. - One specimen observed in the wall of the building of the Polish Geological Institute, Zgoda street, Kielce, and a few poorly preserved specimens observed in the field.

D e s cription. - Hypichnial, generally horizontal, curved, loosely spaced branched ridges arranged in an indistinct fan, preserved in semi-relief in a bioturbated sandstone 
bed. At least six branches diverge probably from a common stem, but the meeting point of the branches and the common stem are not preserved. Parts of the ridges are almost parallel to each other, while others are divergent. The ridges are circular to oval in cross-section, $8-12 \mathrm{~mm}$ wide, $\sim 13 \mathrm{~mm}$ long. Their surface is rough, even or indistinctly undulose.

$\mathrm{R}$ e marks. - The specimen described is poorly preserved; however, its morphological features are shared with Phycodes circinatus Richter, 1850 (cf. Häntzschel, 1975; Fillion and Pickerill, 1990; Seilacher, 2000; Stachacz, 2016). Phycodes is a fodinichnion produced by unknown organisms; in the Paleozoic it is known mostly from shallow-marine strata (e.g., Osgood, 1970; Fillion and Pickerill, 1990; Seilacher, 2000; Hanken et al., 2016).

\section{?Ptychoplasma isp.} (Fig. 6J)

M a t e r i a I. - Several specimens observed in the wall of the building of the Polish Geological Institute, Zgoda street, Kielce.

D e s c ri pti o n. - Hypichnial ridges $12-20 \mathrm{~mm}$ wide, composed of oval, arrow-shaped or irregular, smooth pads; some of which are separated by more even segments. The pads are $10-40 \mathrm{~mm}$ long, $\sim 10 \mathrm{~mm}$ high and only slightly wider than the even ridge. The overall course is straight or gently winding; some segments intersect.

Remarks. - The fill shows some similarities to Torrowangea rosei Webby, 1970, but the latter taxon is distinctly sinuous to meandering and much smaller (cf. Webby 1970; Gámez Vintaned et al., 2006). Ptychoplasma is a locomotion trace of molluscs; it is known since the Cambrian (Uchman et al., 2011).

\section{DISCUSSION}

\section{DEPOSITIONAL ENVIRONMENT}

The recognizable trace fossils from the Bukówka Formation are relatively of low diversity, and show infrequent and usually bad preservation. The ichnoassemblage consists of eleven ichnotaxa, including fodinichnia (Teichichnus, Phycodes, Ptychoplasma), pascichnia (Cruziana, Planolites, Palaeophycus), domichnia (Skolithos, Catenarichnus) and cubichnia (Rusophycus). The presence of both horizontal and vertical burrows is typical of the archetypal and proximal Cruziana ichnofacies suggesting deposition in the upper to lower shoreface with storm influences (cf. Pemberton et al. 2001). Some parts of the formation may belong to the Skolithos ichnofacies (sensu Seilacher, 1967) but any series of beds containing exclusively vertical traces has not been observed in the field. The interpretation of ichnofacies is in accordance with the presence of hummocky cross-stratification, low-angle cross-lamination, ripple laminations and horizontal lamination (Fig. 2), a set of primary sedimentary structures typical of a wave- and storm-dominated shoreface. The lower part of the Bukówka Formation, which is represented by thick-bedded sandstones bearing irregularly scattered brachiopod coquina beds, lenticular brachiopod accumulations, and shell pavements might be referred to a periodic intensification of storm events (cf. Dżułyński and Kubicz, 1975; Kidwell, 1986). The skeletal fossils are well-preserved, suggesting their rapid burial. (cf. Brett and Baird, 1988). In this part of the formation, the degree of bioturbation is high. However, the bioturbation structures are subtle and small. The lack of in-situ rotations of shells in shell pavements suggests bioturbation only by small organisms. The shell accumulations and the preservation of primary sedimentary structures indicate higher-energy episodes with rapid sedimentation when the colonization window was too brief. However, the prevailing bioturbated sediments suggest a mostly low accumulation rate and longer colonization window after the storm events, enabling obliteration of primary structures by burrowing organisms. The sedimentological data indicate that the sedimentation rate of the Bukówka Formation varied. Strongly bioturbated sandstones of the upper part of the formation required a very low sedimentation rate, when bioturbation reworking balanced the sediment accumulation. A low sedimentation rate in the basin is also suggested by firmgrounds, the presence of which is indirectly evidenced by intraclasts.

The postulated overall low sedimentation rate interrupted by short-term storm events is partly in opposition to the view of Bednarczyk and Biernat (1978), who concluded that the formation, $30 \mathrm{~m}$ thick, was rapidly deposited in the eastern and the western nearshore margins of the basin, as opposed to the central area, including the Kielce (also the sections at Mójcza in this study) and the Bardo Syncline areas, where the sedimentation rate was much lower; all because of tectonic activity during the Floian and Dapingian.

The absence of well-preserved trace fossils, especially cruzianids, was probably caused by intense bioturbation of the sandy deposits (ichnofabric index 4-6 sensu Droser and Bottjer, 1986) and the absence of muddy intercalations which would have a large positive influence on the preservation potential of such structures, especially their scratch traces. The highest preservation potential for such traces is in heterolithic siltstone-sandstone deposits. Also the presence of brachiopod shell grounds limited burrowing activity and decreased the preservational potential of traces.

Taking into account the duration of deposition of the Bukówka Formation that lasted 4.5-5 My (from the late Dapingian to the early Darriwilian) and its maximum thickness, an average sedimentation rate of $9 \mathrm{~cm} / 1000 \mathrm{y}$ is estimated. This is a low value for shallow-marine sandy sediments, supported by the generally high bioturbation degree of the sandstones investigated. Up-section, the sedimentation rate in the Kielce Region was generally even lower as can be inferred from the overlying condensed limestones of the Mójcza Formation (Dzik and Pisera, 1994; Trela, 2005b). The transition from bioturbated quartz sandstones with storm accumulations of brachiopod shells through sandstones (especially wackes) with firmground intraclasts and rarely mudstones with intercalations to calcareous sandstones and sandy limestones indicates a decreasing frequency of storm events, progressive reduction in wave/current strength and gradual cessation of clastic deposition. Such changes in sedimentation character are usually attributed to sea level rise. This interpretation is also supported by gradual replacement of clastic deposition by carbonates toward the top of the formation and the presence of highly condensed limestones overlying the Bukówka Formation (Trela, 1998, 2006). According to Trela (2017), the Bukówka Formation was deposited during regression following the early Dapingian (Baltoniodus navis Zone) transgression, which was recorded also in the Łysogóry Region (Trela, 2008). The condensed Mójcza Limestone overlying the Bukówka Formation was deposited during the next transgressive phase which started in the late Darriwilian Pygodus serra Zone (Trela, 2005a, b, 2006). The discontinuity marking the boundary between the Bukówka 
Formation and the Mójcza Formation (Trela, 2006) is associated with submarine erosion that took place during a sea level fall and was interpreted as the Viruan discontinuity surface known from Sweden (Dzik and Pisera, 1994). The Viruan discontinuity is connected with a global eustatic sea level fall that took place in Baltoscandia (Holmer, 1983). A worldwide long-term sea level fall took place from the Dapingian to early Darriwilian, which was interrupted by higher frequency short-term sea level rises and falls (Dronov and Holmer, 1999; Haq and Schutter, 2008; Dronov et al., 2011; Dronov, 2017).

According to Trela (2004), the Ordovician of the Małopolska Block records three highstands and lowstands associated with second order sea level changes. However, tectonic activity in the Holy Cross Mountains during the Ordovician influenced the sedimentary record of these cycles, and, as a result, the sequence boundaries here have a local meaning (Trela, 2008). Moreover, the facies and sedimentation rate distinctly varied (Bednarczyk and Biernat, 1978). Nevertheless, the fossil record in the Holy Cross Mountains displays a generally long-term transgressive trend during the Ordovician (cf. Haq and Schutter, 2008: fig. 1), whilst strongly bioturbated, storm-dominated sandstones of the Bukówka Formation were deposited during a brief interval of relatively low sea level, or short-term regression, as postulated Trela (2017). The transition from siliciclastic to carbonate facies at the top of the Bukówka Formation is interpreted in this study as a short-term transgression record, which represents the second of the two lower-order transgressive pulses that occurred during the late Dapingian and early Darriwilian from $\sim 470 \mathrm{Ma}$ to $464 \mathrm{Ma}$ (cf. Trela, 2005a, fig. 7; Haq and Schutter, 2008: fig. 1).

THE BUKÓWKA FORMATION IN THE CONTEXT

OF THE ICHNOLOGY OF BALTICA AND GONDWANA AREAS

The location of the Bukówka Formation between the main landmasses of Baltica and Gondwana makes it important in the discussion of ichnological differences between the deposits of these continents, even though the data are hampered by poor exposure of the deposits and poor preservation of their trace fossils. The limestones of the overlying Mójcza Formation are highly condensed and homogenized by bioturbation, in contrast to Ordovician limestones of the Baltica margin, which are also bioturbated, commonly condensed but locally contain well-preserved trace fossils (e.g., Dronov et al., 2002; Cherns et al., 2006; Dronov and Mikuláš, 2010; Knaust et al., 2012; Dronov,
2013; Knaust and Dronov, 2013; Vinn et al., 2014b, 2015; Vinn and Toom, 2016; Toom et al., 2017).

Quartz sandstone-dominated facies of the same age as the Bukówka Formation are known in peri-Gondwanan areas, mostly in the Armorican Quartzite Formation, the facies and ichnology of which are well-known from the Iberian Peninsula and France (references below). They are relatively poorly bioturbated, but they contain diverse and usually well-preserved ichnoassemblages, which include at least 35 ichnospecies of 20 ichnogenera described by several authors (Rouault, 1850; Romano, 1974, 1991; Crimes and Marcos, 1976, Baldwin, 1977a, b; Pickerill et al., 1984; Durand, 1984, 1985a, b; Aceńolaza et al., 2008; Rodríguez-Tovar et al., 2014). Another peri-Gondwanan (Avalonian) unit, i.e. the Bell Island Group of Newfoundland, similar to the Armorican Quartzite and partly of the same age, includes 97 ichnotaxa (Fillion and Pickerill, 1990). The Bell Island Group is also distinctly less bioturbated than the Bukówka Formation. The thickness of these units is much larger than that of the Bukówka Formation, i.e. $1390 \mathrm{~m}$ for the Bell Island Group (Fillion and Pickerill, 1990 ) and up to $600 \mathrm{~m}$ (usually 150-300 m but in some cases $<10 \mathrm{~m}$ ) for the Armorican Quartzite (Gutiérrez-Marco et al., 2002). This suggests their much higher sedimentation rate and, as a consequence, deeper burial of organic matter and its higher content deeper in the sediment (cf. Ingall and Cappellen, 1990). Low sedimentation rate causes a low burial rate of organic matter (Müller and Suess, 1979; Jung et al., 1997; Löwemark et al., 2006) which is concentrated shallowly in the sediment, consumed and burnt down in oxic environments (Wetzel and Uchman, 2017). Accordingly, a higher sedimentation rate causes deeper burial of organic matter, which attracted burrowing organisms. In the case of the peri-Gondwanan areas, the relatively high sedimentation rate promoted both deeper burrowing and better preservation of trace fossils. A slow sedimentation rate in Baltica caused quick decomposition of organic matter and its shallow burial. Shallow burrowing negatively influenced the diversity of traces and their preservation. The preservation potential of trace fossils in sandy deposits of the Bukówka Formation was much lower than in many Avalonian and peri-Gondwanan sections (e.g., d'Orbigny, 1842; Rouault, 1850; Lebesconte, 1883, 1886; Delgado, 1886; Seilacher, 1970; Baldwin 1977a; Durand, 1984, 1985a, b; Fillion and Pickerill, 1990; Neto de Carvalho, 2006), and comparable to the siliciclastic-cool water carbonaceous sediments of Baltica that contain similar burrows plus borings $(\sim 20$
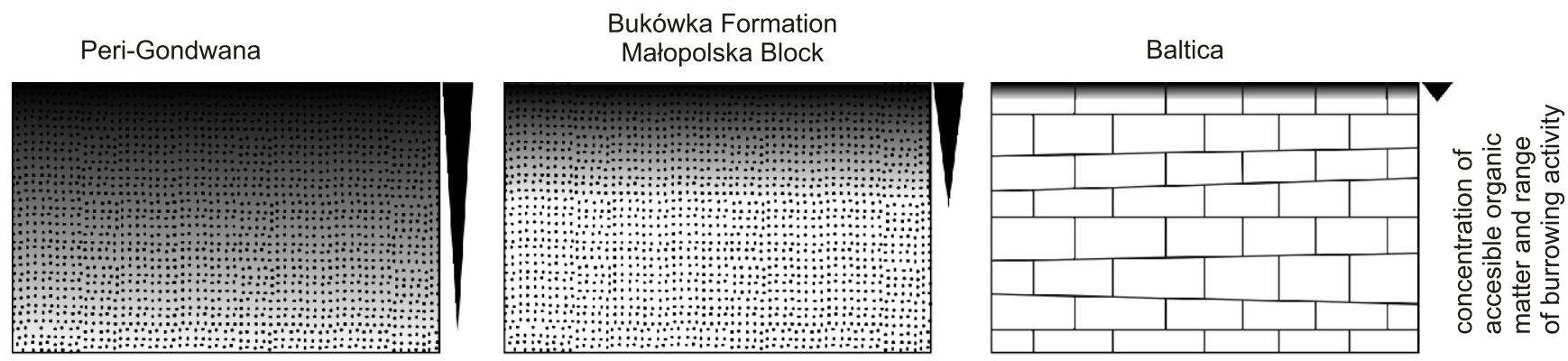

Deposition rate, preservation potential of primary sedimentary structures and increase in ichnodiversity

Fig. 7. Model of differences in the ichnological record between peri-Gondwana, the Małopolska Block and Baltica during the Ordovician, the differences depend on accumulation rate, burial of organic matter and depth of burrowing 
ichnotaxa, based on: Cherns et al., 2006; Dronov and Mikuláš, 2010; Vinn and Wilson, 2010; Knaust et al., 2012; Knaust and Dronov, 2013; Vinn et al., 2014a; Vinn and Toom, 2016; Toom et al., 2017). This fact explains the provincial differences in the Ordovician ichnoassemblages of Gondwana and Baltica, which were at least partly driven by the regional preservation conditions. Nevertheless, the low ichnodiversity and poor preservation of the trace fossils from the Bukówka Formation results also from specific depositional conditions in a shallow-water environment influenced by storms, in which most of the sediment was repeatedly re-deposited because of a lack of accommodation space and relatively strong waves/currents.

The most common trace fossils of the Bukówka Formation have no great stratigraphic and palaeogeographical significance. Nevertheless, the large Cruziana and Rusophycus correspond to the Cruziana imbricata and C. pudica groups (sensu Seilacher, 1970), which are characterized by large sizes of traces and are typical of the peri-Gondwanan realm (e.g. Delgado, 1886; Seilacher, 1970; Durand, 1985a, b; Mángano and Buatois, 2003; Neto de Carvalho, 2006; Neto de Carvalho and Baucon, 2016). The large size of cruzianids is attributed to cool-water conditions at high latitudes and 'polar gigantism' (Dronov, 2013; Neto de Carvalho and Baucon, 2016) and this concerns also Ordovician of the Małopolska Block. They are rarely noted in Baltica. Nevertheless, trilobite burrows preserved with their body fossils in the Middle Ordovician limestones of Sweden were illustrated by Cherns et al. (2006). Moreover, Kushlina and Dronov (2011) described a giant Ordovician Rusophycus from Siberia. Vinn and Toom (2016) analysed other arthropod traces from the carbonate facies in the Ordovician and Silurian of Estonia. Knaust (2004) reported a few trilobite trace fossils from the Baltica margins of Norway, resembling those from the Gondwanan realm. Moreover, the presence of Rusophycus ?pudicus in the peri-Baltic Bukówka Formation suggests its similarities to the peri-Gondwanan (including Avalonia) realm. The prevailing cool-water carbonate and condensed facies in Baltica are characterized by a scarcity of cruzianids. Also, other trace fossils reported from the carbonate rocks of Baltoscandia are usually poorly preserved and moderately diverse (Vinn and Toom, 2016, Toom et al., 2017). This could be an effect of generally shallow burrowing and much lower preservation potential in the carbonate (even in detrital carbonate) than siliciclastic settings, especially in the case of very low sedimentation rates in cool water carbonate environments (Fig. 7). However, in some settings, trace fossils in carbonate facies can be well-preserved, e.g. by conservation of the sediment surface, including traces, by microbial mats and biofilms (Knaust et al., 2012). The clastic deposits of the Bukówka Formation with rare and relatively large cruzianids may represent a similar deposition rate to that of the cool-water limestones of Baltica (cf. Dronov, 2013).

Deep sediment burrowing is a less effective way of feeding in condensed facies, where food is concentrated on or very near the sediment-water interface. Moreover, early cementation at shallow depths in the sediment and the common formation of firm- and hardgrounds do not favour burrowing. In such situations, burrows or borings of sessile benthic organisms are more frequent, as in the case of Baltica. Summarizing, it seems that the ichnological differences among Gondwana, Baltica, and terranes did not result purely from the palaeogeographic ranges of trace makers, but instead were strongly influenced by taphonomic processes related to sedimentation rate and burial of organic matter.

\section{CONCLUSIONS}

The Middle Ordovician Bukówka Formation shows poorly preserved trace fossils of low diversity, including large Cruziana and Rusophycus probably belonging to the Cruziana imbricata group. They indicate that this formation was deposited in a wave-dominated shoreface with storm episodes during a general transgression. The trace-making organisms evidently burrowed shallowly because organic matter was concentrated near the sediment-water interface in a generally low sedimentation rate regime. Differences in sedimentation rate, the burial of organic matter and sediment type were the factors which strongly influenced ichnological differences between the Ordovician of Baltica, Gondwana, and terrains located between them, including the Małopolska Block on which the Bukówka Formation occurs.

Acknowledgements. Jagiellonian University supported the studies by M.S. (DSC funds, no. DS/MND/WbiNoZ/ING/1/2012), W. Ł. (DSC funds, no. DS/MND/WbiNoZ/ING/2016) on the Ordovician rocks in the Holy Cross Mountains, and by A.U. (DS, K/ZDS/005424). A. Dronov (Moscow, Russia), A. Sá (Vila Real, Portugal), W. Trela (Kielce, Poland) and O. Vinn (Tartu, Estonia) provided constructive reviews, however, some reviewer's opinions have not been followed. Andrew K. Rindsberg improved the English in most of the paper.

\section{REFERENCES}

Aceñolaza, G.F., Sá, A.A., Gutiérrez-Marco, J.C., 2008. Cruziana yini Yang, a Peri-Gondwanan trilobite trace with new records in the Ordovician of South America and Iberia. Publicaciones del Instituto Geológico y Minero de España, Serie: Cuadernos del Museo Geominero, 9: 19-26.

Alpert, S.P., 1974. Systematic review of the genus Skolithos. Journal of Paleontology, 48: 661-669.

Baldwin, C.T., 1977a. Rusophycus morgati: an asaphid produced trace fossil from the Cambro-Ordovician of Brittany and northwest Spain. Journal of Paleontology, 51: 411-425.

Baldwin, C.T., 1977b. Internal structures of trilobite trace fossils indicative of an open surface furrow origin. Palaeogeography, Palaeoclimatology, Palaeoecology, 21: 273-284.
Barnes, C.R., Fortey, R.A., Williams, S.H., 1996. The pattern of global bio-events during the Ordovician period. In: Global Events and Event Stratigraphy in the Phanerozoic (ed. O.H. Walliser): 140-172. Springer, Heidelberg.

Bednarczyk, W., 1971. Stratigraphy and palaeogeography of the Ordovician in the Holy Cross Mountains. Acta Geologica Polonica, 21: 573-616.

Bednarczyk, W., Biernat, G., 1978. Inarticulate brachiopods from the lower Ordovician of the Holy Cross Mountains, Poland. Acta Palaeontologica Polonica, 23: 293-316.

Bednarczyk, W., Stupnicka, E., 2000. Stratigraphy and new data on tectonics of the Ordovician strata in the section at Międzygórz Quarry (eastern Holy Cross Mountains, Poland). Annales Societatis Geologorum Poloniae, 70: 283-297. 
Bergström, S.M, Chen, X., Guitiérrez-Marco, J.C., Dronov, A., 2008. The new chronostratigraphic classification of the Ordovician System and its relations to major regional series and stages and to $\delta^{13} \mathrm{C}$ chemostratigraphy. Lethaia, 42: 97-107.

Billings, E., 1862. New species of fossils from different parts of the Lower, Middle and Upper Silurian rocks of Canada. Palaeozoic Fossils, 1 (1862-1865): 96-168. Geological Survey of Canada, Dawson Brothers, Montreal.

Bradshaw, M., 2002. A new ichnogenus Catenarichnus from the Devonian of the Ohio Range, Antarctica. Antarctic Science, 14: 422-424.

Brett, C.E., Baird, G.C., 1988. Comparative taphonomy: a key to paleoenvironmental interpretation based on fossil preservation. Palaios, 1: 207-227.

Cherns, L., Wheeley J.R., Karis L., 2006. Tunneling trilobites: habitual infaunalism in an Ordovician carbonate seafloor. Geology, 34: 657-660.

Cocks, L.R.M., 2002. Key Lower Palaeozoic faunas from near the Trans-European Suture Zone. Geological Society Special Publications, 201: 37-46.

Cocks, L.R.M., Torsvik, T.H., 2002. Earth geography from 500 to 400 million years ago: a faunal and palaeomagnetic review. Journal of the Geological Society, 159: 631-644.

Cooper, R.A., Sadler, P.M., 2012. The Ordovician Period. In: The Geologic Time Scale 2012 (eds. F.M. Gradstein, J.G. Ogg, M. Schmitz and G. Ogg): 559-601. Elsevier, Amsterdam.

Corner, G.D., Fjalstad, A., 1993. Spreite trace fossils (Teichichnus) in a raised Holocene fjord- delta, Breidvikeidet, Norway. Ichnos, 2: $155-164$.

Crimes, T.P., Marcos, A., 1976. Trilobite traces and the age of the lowest part of the Ordovician reference section for NW Spain. Geological Magazine, 113: 349-356.

Czarnocki, J., 1939. Sprawozdanie $\mathrm{z}$ badań terenowych wykonanych w Górach Świętokrzyskich w 1938 r. Biuletyn Państwowego Instytutu Geologicznego, 15: 1-41.

Delgado, J.F.N., 1886. Étude sur les Bilobites et autres fossiles des quarzites de la base du système Silurique du Portugal. Sections des Travaux Géologiques de Portugal. Académie Royale des Sciences, Lisbonne.

Dronov, A., 2013. Late Ordovician cooling event: Evidence from the Siberian Craton. Palaeogeography, Palaeoclimatology, Palaeoecology, 389: 87-95.

Dronov, A.V., 2017. Chapter 5 - Ordovician Sequence Stratigraphy of the Siberian and Russian Platforms. Special Issue. Stratigraphy \& Timescale, 2: 187-241. Elsevier.

Dronov, A.V., Holmer, L.E., 1999. Depositional sequences in the Ordovician of Baltoscandia. Acta Universitatis Carolinae, Geologica, 43: 133-136.

Dronov, A., Mikuláš, R., 2010. Paleozoic Ichnology of St. Petersburg Region. Field Guide for the 4th International Workshop on Ichnotaxonomy, June 21-25, Moscow-St. Petersburg. Transactions of the Geological Institute, 596: 1-70.

Dronov, A., Mikuláš, R., Logvinova, M., 2002. Trace fossils and ichnofabrics across the Volkhov depositional sequence (Ordovician, Arenigian of St. Petersburg Region, Russia). Journal of the Czech Geological Society, 47: 133-146.

Dronov, A.V., Ainsaar, L., Kaljo, D., Meidla, T., Saadre, T., Einasto, R., 2011. Ordovician of Baltoscandia: facies, sequences and sea-level changes. Cuadernos del Museo Geominero, 14: 143-150.

Droser, M.L., Bottjer, D.J., 1986. A semiquantitative field classification of ichnofabric. Journal of Sedimentary Petrology, 56: 558-559.

Durand, J., 1984. Ichnocenoses du grès Armoricain (Ordovicien Inférieur du Massif Armoricain) dans leur contexte sédimentologique. Geobios, Memoir Special, 8: 189-197.

Durand, J., 1985a. Les traces fossiles paléobiologices de milieux: un exemple dans l'Ordovicien Armoricain. Bulletin du Muséum National d'Histoire Naturelle. Section C, Sciences de la Terre, Paléontologie, Géologie, Minéralogie, C3: 215-227.
Durand, J., 1985b. Les Grès Armoricain. Sedimentologie - Traces fossiles. Milieux de dèpot. Centre Armoricain d'Etude Structurale des Socles, Mémoires et Documents, 3: 1-150.

Dzik, J., Pisera, A., 1994. Sedimentation and fossils of the Mójcza Limestone. Palaeontologia Polonica, 53: 5-41.

Dżułyński, S., Kubicz, A., 1975. Storm accumulations of brachiopod shells and sedimentary environment of the Terebratula Beds in the Muschelkalk of Upper Silesia (southern Poland). Rocznik Polskiego Towarzystwa Geologicznego, 45: 157-169.

Fillion, D., Pickerill, R.K., 1990. Ichnology of the Upper Cambrian? to Lower Ordovician Bell Island and Wabana groups of eastern Newfoundland, Canada. Palaeontographica Canadiana, 7: $1-119$.

Gámez Vintaned, J.A., Liñan, E., Mayoral, E., Dies, M.E., Gozdo, R., Muńiz, F., 2006. Trace and soft body fossils from the Pedroche Formation (Ovetian, Lower Cambrian of the Sierra Cordoba, S Spain) and their relation to the Pedroche event. Geobios, 39: 443-468.

Goldring, R., 1985. The formation of the trace fossil Cruziana. Geological Magazine, 122: 65-72.

Gutiérrez-Marco, J.C., Robardet, M., Rábano, I., Sarmiento, G.N., San José Lancha, M.Á., Araújo, P.H., Pindal, A.P., 2002. Ordovician. In: Geology of Spain (eds. W. Gibbons and T. Moreno): 31-49. The Geological Society, Bath.

Hall, J., 1847. Palaeontology of New York, 1. C. Van Benthuysen, Albany.

Hall, J., 1852. Palaeontology of New York, 2. C. Van Benthuysen, Albany.

Hallam, A., Sweet, K., 1966. Trace fossils from the Lower Cambrian Pipe Rock of the north-west Highlands. Scottish Journal of Geology, 2: 101-106.

Hanken, N.M., Uchman, A., Nielsen, J.K., Olaussen, S., Eggebø, T., Steinsland, R., 2016. Late Ordovician trace fossils from offshore to shallow water mixed clastic and carbonate facies in the Ringerike area, Oslo Region, Norway. Ichnos, 23: 189-221.

Haq, B.U., Schutter, S.R., 2008. A chronology of Paleozoic sea-level changes. Science, 322: 64-68.

Häntzschel, W., 1975. Trace fossils and problematica. In: Treatise on Invertebrate Paleontology (ed. C. Teichert), Part W. Miscellanea, Supplement 1. The Geological Society of America and the University of Kansas, Boulder, Lawrence, W1-W296.

Hofmann, R., Goudemand, N., Wasmer, M., Bucher, H., Hautmann, M., 2011. New trace fossil evidence for an early recovery signal in the aftermath of the end-Permian mass extinction. Palaeogeography, Palaeoclimatology, Palaeoecology, 310: 216-226.

Holmer, L., 1983. Lower Viruan disconformity surfaces in central Sweden. Geologiska Föreningens i Stockholm Förhandlingar, 105: 29-42.

Ingall, E.D., Cappellen, P. van, 1990. Relation between sedimentation rate and burial of organic phosphorus and organic carbon in marine sediments. Geochimica et Cosmochimica Acta, 54: 373-386.

Jung, M., Ilmberger, J., Mangini, A., Emeis, K.-C., 1997. Why some Mediterranean sapropels survived burn-down (and others did not). Marine Geology, 141: 51-60.

Keighley, D.G., Pickerill, R.K., 1995. The ichnotaxa Palaeophycus and Planolites: historical perspectives and recommendations. Ichnos, 3: 301-309.

Knaust, D., 2004. Cambro-Ordovician trace fossils from the SW-Norwegian Caledonides. Geological Journal, 39: 1-24.

Knaust, D., Dronov, A., 2013. Balanoglossites Ichnofabrics from the Middle Ordovician Volkhov Formation (St. Petersburg Region, Russia). Stratigraphy and Geological Correlation, 21: 265-279.

Knaust, D., Curran, A., Dronov, A., 2012. Shallow-marine carbonates. Developments in Sedimentology, 64: 705-750. Elsevier, Amsterdam.

Kidwell, S., 1986. Models for fossil concentrations: paleobiologic implications. Paleobiology, 12: 6-24.

Kushlina, V.B., Dronov, A., 2011. A giant Rusophycus from the Middle Ordovician of Siberia. Ordovician of the World. Cuadernos del Museo Geominero, 14: 279-285. 
Lebesconte, P., 1883. Oeuvres posthumes de Marie Rouault, publiées par les soins de P. Lebesconte, suivies de: Les Cruziana et Rusophycus, connus sous le nom général Bilobites sontils des végétaux ou des traces d'animaux? Savy, Rennes-Paris.

Lebesconte, P., 1886. Constitution générale du Massif breton comparée à celle du Finistérre. Bulletin Société Géologique de France, Série 3, 14 (1886): 776-811.

Löwemark, L., Lin, Y., Chen, H.-F., Yang, T.-N., Beier, C., Werner, F., Lee, C.-Y., Song, S.-R., Kao, S.-J., 2006. Saprope burn-down and ichnological response to late Quaternary sapropel formation in two ca. 400 ky records from the eastern Mediterranean Sea. Palaeogeography, Palaeoclimatology, Palaeoecology, 239: 406-425.

Mángano, G., Buatois, L., 2003. Trace fossils. In: Ordovician Fossils of Argentina (ed. J.L. Benedetto): 507-553. Universidad Nacional de Córdoba, Secretaría de Ciencia y Tecnología.

McCarthy, B., 1979. Trace fossils from a Permian shoreface - foreshore environment, Eastern Australia. Journal of Paleontology, 53: $345-366$.

Müller, P.J., Suess, E., 1979. Productivity, sedimentation rate and sedimentary organic matter in the oceans. I. Organic carbon preservation. Deep-Sea Research, 26: 1347-1362.

Neto de Carvalho, C., 2006. Roller coaster behavior in the Cruziana rugosa group from Penha Garcia (Portugal): implications for the feeding program of trilobites. Ichnos, 13: 255-265.

Neto de Carvalho, C., Baucon, A., 2016. Giant trilobite burrows and their paleobiological significance (Lower-to-Middle Ordovician from Penha Garcia, Portugal). Ichnologia de Portugal e Transfronteiriça. Comunicações Geológicas, 103, Especial 1 71-82.

Ogg, J.G., Ogg, G.M., Gradstein F.M., 2016. A Concise Geologic Time Scale. Elsevier, Amsterdam.

Osgood, R.G., 1970. Trace fossils of the Cincinnati area Palaeontographica Americana, 6: 300-307.

d'Orbigny, A., 1842. Voyage dans l'Amérique méridionale (le Brésil, la République oriental de l'Uruguay, la République Argentine, la Patagonie, République du Chili, la République de Bolivia, la République du Pérou) exécuté pendant les annes 1826, 1827 $1829,1330,1831,1832$, et 1833, pt. 4 (Paléontologie) Pitois-Levrault, Paris and Levrault, Strasbourg.

Pemberton, S.G., Frey, R.W., 1982. Trace fossil nomenclature and the Planolites-Palaeophycus. Journal of Paleontology, 56: 843-881.

Pemberton, S.G., Spila, M., Pulham, A.J., Sounders T., MacEachern, J.A., Robbins, D., Sinclair, I.K., 2001. Ichnology and sedimentology of shallow to marginal marine systems: Ben Nevis and Avalon reservoirs, Jeanne d'Arc Basin. Geologica Association of Canada Short Course, 15

Pickerill, R.K., Romano, M., Meléndez, B., 1984. Arenig trace fossils from the Salamanca area, western Spain. Geological Journal, 19: 249-269.

Richter, R., 1850. As der Thüringischen Grauwacke. Deutche Geologische Gesellschaft, 2: 198-206.

Richter, R., 1937. Marken und Spuren aus allen Zeiten I-II. Senckenbergiana, 19: 193-240.

Rodríguez-Tovar, F.J., Stachacz, M., Uchman, A., Reolid, M. 2014. Lower/Middle Ordovician (Arenigian) shallow-marine trace fossils of the Pochico Formation, southern Spain: palaeoenvironmental and palaeogeographic implications at the Gondwanan and peri-Gondwanan realm. Journal of Iberian Geology, 40: 539-555

Romano, M., 1974. The palaeoenvironment and ichnology of the Lower Ordovician rocks at Ápulia, north Portugal. Boletin do Museu e Laboratório Mineralógico e Geológico da Faculdade de Ciêncas, 14: 63-76.

Romano, M., 1991. Lower to middle Ordovician trace fossils from the Central Iberian Zone of Portugal and Spain. Geological Sur vey of Canada. Paper 90-9: 191-204.

Rouault, M., 1850. Note préliminaire sur une nouvelle formation découverte dans la terrain silurien inférieur de la Bretagne. Bulletin de la Société Géologique de France, Série 2, 7: 724-744.
Salter, J., 1857. On Annelida-burrows and surface makings from the Cambrian rocks of Longmynd. Quarterly Journal of the Geological Society, 13: 199-206.

Schlirf, M., Uchman, A., 2005. Revision of the ichnogenus Sabellarifex Richter, 1921 and its relationship to Skolithos Haldeman, 1840 and Polykladichnus Fürsich, 1981. Journal of Systematic Palaeontology, 3: 115-131.

Seilacher, A., 1955 Spuren und Lebensweise der Trilobiten, Spuren und Fazies im Unterkambrium. Akademie der Wissenschaften und der Literatur, Abhandlungen der mathematich-naturwissenschaftlichen Klasse, 10: 86-141.

Seilacher, A., 1967. Bathymetry of trace fossils. Marine Geology, 5: 413-428.

Seilacher, A., 1970. Cruziana stratigraphy of "non-fossiliferous" Palaeozoic sandstones. Geological Journal, Special Issue, 3: 447-476.

Seilacher, A., 1992. An updated Cruziana stratigraphy of Gondwanan Paleozoic sandstones. The Geology of Libya, 4 1565-1581. Elsevier, Amsterdam.

Seilacher, A., 2000. Ordovician and Silurian arthrophycid ichnostratigraphy. In: Geological Exploration in Murzug Basin (eds. M.A. Sola and D. Worsley): 237-258. Elsevier, Amsterdam.

Seilacher, A., 2007. Trace Fossil Analysis. Springer. Berlin.

Servais, T., Owen, A.W., Harper, D.A.T., Kröger, B., Munnecke, A., 2010. The Great Ordovician Biodiversification Event (GOBE): the palaeoecological dimension. Palaeogeography, Palaeoclimatology, Palaeoecology, 294: 99-119.

Skompski, S., ed., 2015. The Holy Cross Mountains - 25 Journeys through Earth History. University of Warsaw, Faculty of Geology.

Stachacz, M., 2016. Ichnology of the Cambrian Ociesęki Sandstone Formation (Holy Cross Mountains, Poland). Annales Societatis Geologorum Poloniae, 86: 291-328.

Stachacz, M., Rodríguez-Tovar, F.J., Uchman, A., Reolid, M., 2015. Deep endichnial Cruziana from the Lower-Middle Ordovician of Spain - a unique trace fossil record of trilobitomorph deep burrowing behavior. Ichnos, 22: 12-18.

Tomczyk, H., 1962. Stratigraphic problems of the Ordovician and Silurian in Poland in the light of recent studies (in Polish with English summary). Prace Instytutu Geologicznego, 25: 1-134.

Tomczyk, H., Turnau-Morawska, M., 1967. Problems of stratigraphy and sedimentation of the Ordovician in Łysogóry (Holy Cross Mts., Central Poland) in connection with some profiles of the southern region (in Polish with English summary). Acta Geologica Polonica, 17: 1-50

Toom, U., Vinn, O., Hints, O., 2017. A review of ichnofossils from Estonian palaeontological collections. 10th Baltic Stratigraphic Conference, Chęciny 12-14 September 2017, Abstracts and Guide Book, Warszawa: 82-83.

Trela, W., 1998. Sedimentary environment of the condensed Ordovician limestones from Mójcza section (Holy Cross Mts.). Geological Quarterly, 42 (3): 289-300.

Trela, W., 2004. Ordovician sea-level changes in the Małopolska Block (south-eastern Poland). In: WOGOGOB-2004 Conference Materials (eds. O. Hints and L. Ainsaar): 96-97. Tartu University Press, Tartu.

Trela, W., 2005a. Sedimentary environment of the Upper Ordovician in the Kielce region of the Holy Cross Mts (in Polish with English summary). Biuletyn Państwowego Instytutu Geologicznego, 417: 109 -68

Trela, W., 2005b. Condensation and phosphatization of the Middle and Upper Ordovician limestones on the Malopolska Block (Poland): response to paleoceanographic conditions. Sedimentary Geology, 178: 219-236.

Trela, W., 2006. Lithostratigraphy of the Ordovician in the Holy Cross Mountains (in Polish with English summary). Przegląd Geologiczny, 54: 622-631.

Trela, W., 2008. Sedimentary and diagenetic environments of Middle Ordovician iron-rich limestones (Pobroszyn Formation) in the northern Holy Cross Mountains, Poland. Geological Quarterly, 52 (3): 199-212. 
Trela, W., 2017. Stop A13. Zalesie. 10th Baltic Stratigraphic Conference, Chęciny 12-14 September 2017, Abstracts and Guide Book. Warszawa: 124-128.

Uchman, A., Mikuláš, R., Rindsberg, A.K., 2011. Mollusc trace fossils Ptychoplasma Fenton and Fenton, 1937 and Oravaichnium Plička and Uhrová, 1990: their type material and ichnospecies. Géobios, 44: 387-397.

Vinn, O., Toom, U., 2016. Rare arthropod traces from the Ordovician and Silurian of Estonia (Baltica). Neues Jahrbuch für Geologie und Paläontologie Abhandlungen, 280: 135-141.

Vinn, O., Wilson, M.A., 2010. Early large borings from a hardground of Floian-Dapingian age Early and Middle Ordovician in northeastern Estonia (Baltica). Carnets de Géologie, 4, CG2010_L04.

Vinn, O., Wilson, M.A., 2013. An event bed with abundant Skolithos burrows from the late Pridoli (Silurian) of Saaremaa (Estonia). Carnets de Géologie, 13: 83-87.

Vinn, O., Wilson, M.A., Mõtus, M.-A., 2014a. The earliest giant Osprioneides borings from the andbian (Late Ordovician) of Estonia. PLoS ONE, 9, e99455.
Vinn, O., Wilson, M.A., Zatoń, M., Toom, U., 2014b. The trace fossil Arachnostega in the Ordovician of Estonia (Baltica). Palaeontologia Electronica 17.3.41A: 1-9.

Vinn, O., Wilson, M.A., Toom, U., 2015. Distribution of Conichnus and Amphorichnus in the early Paleozoic of Estonia (Baltica). Carnets de Géologie, 15: 269-278.

Webby, B.D., 1970. Late Precambrian trace fossils from New South Wales. Lethaia, 3: 79-109.

Webby, B.D., Cooper, R.A., Bergström, S. M., Paris, F., 2004. Stratigraphic framework and time slices. In: The Great Ordovician Biodiversification Event (eds. B.D. Webby, F. Paris, M.L. Droser and I.G. Percival): 41-47. Columbia University Press, New York.

Wetzel, A., Uchman, A., 2017. The former presence of organic matter caused its later absence: Burn-down of organic matter in oceanic red beds enhanced by bioturbation (Eocene Variegated Shale, Carpathians). Sedimentology, doi: 10.1111/sed.12436 